\title{
Gorontalo
}

\author{
Journal of Government and Political Studies \\ Volume 3 - NO. 2 - Oktober 2020 \\ P-ISSN: 2614-2120 E-ISSN: 2614-2104
}

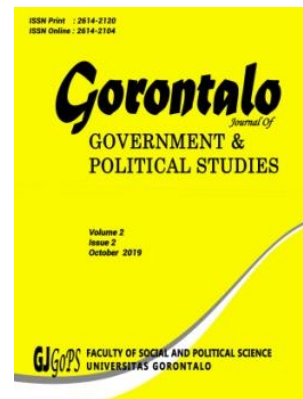

\section{Mencermati Populisme Pemimpin Lokal Sebagai Upaya Membangun Citra Ditengah Pandemi Covid-19}

\author{
Fairuz Arta Abhipraya ${ }^{1}$ \\ Nur Aliv Vidayat ${ }^{2}$ \\ Wahyu Adi Pamungkas ${ }^{3}$ \\ Department of Government Affairs and Administration, \\ Universitas Muhammadiyah Yogyakarta ${ }^{1}$ \\ Jalan Brawijaya, Geblagan, Tamantirto, Kec. Kasihan, Bantul, \\ Daerah Istimewa Yogyakarta 55183 \\ Department of Management ${ }^{2}$ \\ Department of Accountancy ${ }^{3}$ \\ Universitas Pancasakti Tegal, \\ Jalan Halmahera, Mintaragen, $\mathrm{Kec}^{3}$ Tegal Timur, \\ Kota Tegal, Jawa Tengah 52121 \\ fairuz.arta.fisip17@mail.umy.ac.id
}

Received: 10th August 2020; Revised: 13th September 2020;

Accepted: 17th September 2020

\begin{abstract}
This article aims to analyze the leadership and populist policies of Dedy Yon Supriyono as Tegal Mayor in overcoming the COVID-19 pandemic. Furthermore, this paper identifies efforts to build his positive image through a populist leadership style during the COVID-19 pandemic. This article uses a qualitative research method with descriptive analysis techniques. The data collection technique uses literature study, the researchers collect perspectives and literature findings that are related to the research focus. The researchers first construct an initial hypothesis to guide the analysis of the phenomenon that being studied. Furthermore, the researchers conduct an in-depth analysis to the focus study in order to examines the initial hypothesis. The conclusion of this research is that Dedy as the Mayor of Tegal City in responding crisis caused by COVID-19 pandemic uses a populist leadership style, this is proven by the way he acts like a hero for society, creates prosociety narratives, build his self-image of being Mr. Lockdown through various media, optimism bias, and the controversial populist policy such as local lockdown. These things contributed to build the positive image of Dedy through the mass media as a local leader who has successfully handled the pandemic and has become a public conversation. Dedy is considered successful in analyzing the momentum to implement the populist policies and his populist leadership style, so this has an impact on creating a positive image of Dedy as a local leader in dealing with COVID-19 pandemic.
\end{abstract}

Keywords: populism; local leader; mayor of Tegal City; Covid-19 pandemic

ABSTRAK
Tulisan ini bertujuan untuk menganalisis gaya kepemimpinan dan kebijakan populis
walikota Tegal Dedy Yon Supriyono dalam mengatasi pandemi COVID-19. Lebih lanjut,
tulisan ini mengidentifikasi upaya pembangunan citra positif melalui gaya 
kepemimpinan populis selama pandemi COVID-19. Tulisan ini menggunakan metode penelitian kualtitatif dengan teknik deskriptif analisis. Teknik pengumpulan data pada tulisan ini adalah dengan menggunakan teknik studi pustaka, penulis mengumpulkan berbagai sudut pandang dan temuan literatur yang memiliki keterkaitan dengan fokus penelitian. Pada kerangka analisis, penulis pertama-tama membangun sebuah hipotesis awal mengenai fokus penelitian, guna menuntun analisis dari fenomena yang tengah diteliti. Selanjutnya maka peneliti akan melakukan analisis mendalam mengenai fokus penelitian untuk menguji hipotesis awal melalui data-data yang telah dikumpulkan dari upaya sudi pustaka. Simpulan dari penelitian ini adalah Dedy selaku Walikota Tegal dalam merespon krisis akibat pandemi COVID-19 menggunakan gaya kepemimpinan populis, hal ini dibuktikan dengan dia bertindak layaknya pahlawan ditengah pandemi, menciptakan narasi yang pro rakyat, memasarkan citra diri atas kebanggaanya menjadi Mr.Lockdown melalui berbagai media, optimisme bias, hingga kebijakan populis lockdown yang kontroversial. Hal-hal tersebutlah yang turut berkontribusi dalam mengupayakan citra positif Dedy melalui media massa sebagai pemimpin lokal yang berhasil menangani pandemi hingga menjadi perbincangan publik. Dedy dinilai berhasil dalam membaca momentum yang tepat untuk menerapkan kebijakan dan gaya kepemimpinan populisnya, sehingga ini berdampak pada terciptanya citra positif Dedy sebagai pemimpin lokal dalam menangani pandemi.

Kata kunci: populisme; pemimpin lokal; walikota Tegal; pandemi Covid-19

\section{PENDAHULUAN}

Semenjak merebaknya Pandemi COVID-19 di dataran Tiongkok pada Desember 2019 silam, Indonesia sejak maret 2020 kemarin juga turut terdampak dan menyebabkan masyarakat panik (Nuraini, 2020). Dalam kondisi seperti ini, pemerintah Indonesia sedang dalam tahap diuji melalui berbagai kebijakan dan gaya kepemimpinanya untuk menangani pandemi COVID-19. Pemerintah Indonesia harus bisa menjaga konduktifitas masyarakat melalui kebijakan prefentifnya agar tidak terjadi kepanikan didalam kehidupan masyarakat. Namun hal yang perlu disayangkan adalah ketika Sebagian besar negara menutup akses masuk turis asing ke negaranya akibat merebaknya pandemi COVID-19 di dataran Tiongkok pada Desember 2019 silam, Indonesia justru melakukan sebaliknya dan bahkan memberikan diskon kepada turis asing untuk datang ke Indonesia (Fitra, 2020). Ditambah lagi untuk memperburuk keadaan, menjelang periode pandemi COVID-19 pemerintah Indonesia justru melayangkan berbagai retrorika 'blunder' yang terkesan meremehkan keberadaan pandemi COVID-19 dan optimis jika Indonesia tidak akan terjangkit virus tersebut (Mawardi, 2020). Titik puncak kepanikan adalah ketika pada bulan maret 2020, salah satu warga Kota Depok terjangkit virus ini yang sontak membuat kepanikan publik mencuat, dibuktikan dengan kejadian panic buying yang terjadi (Ihsanuddin, 2020).

Pada kondisi kepanikan seperti ini akibat dari pandemi COVID-19, para pemimpin berusaha untuk bisa tampil sebagai sosok yang mampu menangani keadaan krisis ini. Mereka seakan dituntut untuk bisa menangani krisis dengan mengimplementasikan kebijakan-kebijakan yang tepat, juga tampil sebagai sosok yang bisa diandalkan ditengah krisis akibat pandemic COVID-19. Hal ini juga turut berkontribusi untuk melahirkan pola kepimimpinan yang populis untuk memberikan rasa aman kepada masyarakat, artinya bahwa para pemimpin lokal yang populis dalam beberapa momentum berperan bagaikan sosok pahlawan bagi masyarakat (Lee, 2017). Jike Lee telah menggambarkan 
sosok pemimpin populis, didalam (Goodhart \& Lastra, 2018) lebih menekankan pada pendapat bahwa kaum populis muncul akibat dari ketidakpuasan publik atas status quo yang tengah terjadi, biasanya karena ada dampak dari resesi ekonomi yang signifikan.

Selaras dengan (Canovan, 1999) bahwa kaum populis menjadikan institusi demokrasi sebagai lahan untuk menggalang dukungan dengan cara mendekati kelompok yang dirasa diwakilinya. Ketiga pendapat diatas baik dari Lee, Goodhart\&Lastra, dan Canovan menggambarkan bahwa sosok pemimpin populis sangat didambakan oleh masyarakat terutama ditengah keadaan krisis untuk memberikan kepastian, minimal bisa melepas dahaga masyarakat dari ketidakpastian akibat krisis dalam jangka waktu yang pendek. Setidaknya Lee berhasil memotret sosok pemimpin yang bisa dianggap sebagai pahlawan pada momentum tertentu.

\section{Populisme dan Gaya Kepemimpinan}

Konsep populisme muncul untuk mengisi sebuah kekosongan ruang dengan berbagai sudut pandang dan ide, banyak sarjana yang telah mengkaji mengenai populisme hingga menumpuk menjadi berbagai ide dan sudut pandang ilmiah. Kajian mengenai populisme diawali dengan gerakan petani dari Rusia dan Amerika Serikat pada akhir abad ke-19, lalu pada abad ke-20 dilanjutkan dengan kebangkitan populisme di Amerika Latin, hingga pada periode ini populisme sudah merebak di berbagai negara Eropa, Amerika Serikat, dan Amerika Latin (Gidron \& Bonikowski, 2013). Akan tetapi, perdebatan mengenai kemunculan populisme di Indonesia baru ditempatkan pada perdebatan yang ilmiah sejak kurang lebih satu dekade terakhir. Pada rentang kekosongan waktu itu, banyak dari para sarjana yang mulai mengambil perhatian lebih terhadap fenomena populisme di Indonesia (Hadiz \& Robison, 2017; Kusumo \& Hurriyah, 2019; Mietzner, 2015; Pratikno \& Lay, 2013).

Dalam mendiskusikan topik mengenai gaya kepemimpinan, isu mengenai populisme juga sudah tidak bisa dilepaskan dari diskusi tersebut. Beberapa sarjana telah mencoba memberikan definisi konseptual dalam memandang populisme. Seperti didalam (Sahab, 2017) yang memaknai populisme dalam kepemimpinan sebagai sebuah retorika politik, yang menilai bahwa keutamaan dan keabsahan politik terletak pada rakyat sebagai nilai absolut. Artinya bahwa kepemimpinan yang populis meletakan rakyat diatas segalanya, maka dari itu pemimpin yang populis akan mendapatkan simpati lebih dari publik. Karena menurut Richard Hofstadter didalam mahakarya milik (Collins, 1989) telah memberikan sudut pandang umum bahwa populisme akan berorientasi pada agenda untuk membangun program-program yang berpotensi mengembangkan masyarakat. Didukung oleh (Laclau, 2005) yang menggambarkan bahwa populisme adalah sebuah logika politik, artinya adalah sebuah konsekuensi dari kondisi politik yang tengah terjadi ditengah masyarakat. Secara garis besar Laclau menjelaskan bahwa pemimpin populis memiliki orientasi tertentu, yaitu orientasi kepada masyarakat dan permintaan sosial yang dihasilkan dari ketidakpuasan masyarakat terhadap kondisi sosial ekonomi.

Kemunculan pendapat lainya seperti oleh (Lee, 2017) Kembali menjelaskan bahwa populisme telah memisahkan dua polarisasi homogen dan antagonistic seperti kedua kutub magnet yan berbeda, kedua kutub magnet yang berbeda ini digambarkan sebagai orang-orang baik yang mencoba untuk melawan elit korup 
sebagai orang jahat yang tidak berorientasi kepada kesejahteraan masyarakat. Merujuk pada penelitian milik Power Welfare and Democracy Universitas Gadjah Mada didalam (Savirani et al., 2014), populisme dianggap sebagai strategi politik ala Manichean yang melingkupi 3 dimensi, antara lain: pertama, populisme sudah dipastikan akan mengacu pada rakyat. Para pemimpin yang populis pada umumnya akan memberi klaim bahwa mereka bertindak sesuai dengan kehendak rakyat, artinya para pemimpin populis percaya bahwa segala tindakan yang mereka lakukan sudah sesuai dengan permintaan rakyat dan mewakili rakyat secara keseluruhan. Maka dari itu, tidak heran jika (Lee, 2017) menggambarkan populisme sebagai kehendak dari khalayak umum. Kedua, populisme sangat berpotensi dikaitkan dengan ide-ide untuk memperkuat atau bahkan menciptakan relasi antara rakyat dan para pemimpin populis secara langsung. Ketiga, strategi politik yang populis secara signifikan akan melahirkan sentiment-sentimen anti kemapanan dan anti elit.

\section{Memahami Kebijakan Populis dan Pencitraan}

Kebijakan yang populis sangat berkaitan erat dengan citra dari para pemimpin lokal yang populis, artinya bahwa salah satu tujuan dari populisme seorang pemimpin lokal adalah untuk membangun citra positif dihadapan masyarakat yang merasa diwakilinya. Menurut (Nimmo, 1976), yang menjelaskan bahwa citra adalah segala hal yang memiliki keterkaitan dengan kondisi/situasi keseharian dari seorang individu, menyangkut sebuah pengetahuan, perasaan, dan kecenderunganya terhadap sebuah hal, sehingga citra dapat berpotensi untuk berubah dengan seiring berjalanya waktu. Sebuah bentuk pencitraan politik mampu mempengaruhi opini masyarakat, dengan terbentuknya opini masyarakat berdasarkan dari tujuan citra itu dibuat maka masyarakat akan terpengaruh dari aspek sikap dan perilaku politiknya (Rosenberg et al., 1991). Salah satu tujuan dari pemimpin adalah untuk menarik perhatian publik melalui citra positifnya, sehingga dalam mengupayakan hal tersebut dibutuhkan kebijakan-kebijakan populis yang langsung bersinggungan dengan masyarakat untuk diimplementasikan.

Sebuah strategi dalam penerapan kebijakan yang populis tidak membutuhkan mobilisasi gerakan masyarakat atau bahkan tidak membutuhkan dukungan dari fraksi partai politik yang kuat dalam instrument demokrasi, akan tetapi strategi ini lebih cenderung digantungkan pada bagaimana usaha seorang pemimpin populis untuk mengupayakanya (Savirani, 2016). Artinya adalah implementasi kebijakan populis merupakan sebuah strategi untuk membentuk citra keberpihakan kepada masyarakat, Savirani juga mencoba menjelaskan bahwa para pemimpin daerah cenderung terus mempromosikan kebijakan populisnya yang langsung bersinggungan dengan kesejahteraan masyarakat.

\section{Pemimpin Populis di Aras Global, Nasional dan Lokal}

Jika mencermati mengenai gaya kepemimpinan populis ditengah pandemi COVID-19, mayoritas konsep tentang populisme yang telah dijelaskan oleh para sarjana cenderung membuktikan kehadiranya di kejadian nyata. Dalam berbagai fenomena pemimpin populis ditengah pandemi COVID-19, secara global kita disuguhkan tentang wacana populis dari berbagai pemimpin negara di dunia. Seperti yang dijelaskan dalam (Lassa \& Booth, 2020) ada Donald Trump di Amerika dan Jair Bolsonaro di Brazil yang kebijakan serta wacananya merasa 
menjadi terdepan bersama rakyat yang mereka wakili ditengah pandemi COVID19. Dalam penjelasan Lassa \& Booth juga menjelaskan pada ranah nasional, yang menyebutkan Jokowi sebagai pemimpin populis ditengah pandemi karena telah memenuhi beberapa karakteristik pemimpin populis.

Menariknya kajian mengenai populisme pemimpin lokal ditengah keadaan krisis akibat dari pandemi COVID-19 belum banyak didiskusikan, sehingga tulisan ini akan semakin menjadi lebih menarik lagi. Padahal sudah banyak pembahasan mengenai populisme pemimpin lokal di Indonesia sebelumnya (diluar keadaan pandemi), namun pembahasanya belum menjamah pembahasan terkait gaya populisme pemimpin lokal ditengah pandemi COVID-19. Jika ditelaah kembali, apa yang disampaikan oleh (Lee, 2017) tentang sosok pemimpin populis yang berperan seperti pahlawan cenderung merujuk pada beberapa pemimpin lokal di Indonesia, seperti contohnya kita disuguhkan pemimpin lokal yang populis seperti Tri Risma sebagai walikota Surabaya, Ridwan Kamil sebagai walikota Bandung, Nurdin Abdullah bupati Bantaeng, dan Suryono selaku Bupat Bojonegoro (Savirani, 2016). Mereka adalah pemimpin yang dikenal memiliki loyalitas tinggi kepada masyarakat dan dedikasi yang cukup untuk dikategorikan sebagai pemimpin populis, sebab kebijakan serta wacananya merasa menjadi terdepan bersama rakyat yang mereka wakili. Hal ini sejalan dengan (Müller, 2016) pemimpin populis akan mengklaim bahwa dia adalah satu-satunya orang yang paling bisa mewakili kehendak masyarakat secara luas.

Melihat kebangkitan para pemimpin populis ditengah krisis akibat pandemi COVID-19, bisa jadi kebangkitan gaya kepemimpinan populis yang mereka ambil bukan akibat dari watak dan sifat asli yang mereka miliki, tetapi karena ada sebuah momentum yang bisa dimanfaatkan dan ada desakan politik untuk mengumpulkan dukungan dalam agenda membangun citra positifnya. Hal ini semakin diperkuat dengan kehadiran fenomena politik yang berbasis individual atau dikenal dengan "figur-based politics" yang akan menduduki posisi penting seperti didalam skala pemimpin daerah (Savirani et al., 2014). Tentunya momentum untuk mengupayakan citra positif dengan gaya populis dari seorang pemimpin lokal sangat bisa dimanfaatkan, terlebih lagi tambahan bahwa popularitas adalah logika yang telah mendominasi faktor yang mendorong perkembangan iklim politik di Indonesia saat ini serta gambaran dari seorang pemimpin yang bersih,transparan, dan otentik menjadi gambaran dominan sebuah popularitas.

Dalam periode krisis akibat dari pandemi COVID-19 di Indonesia, peran pemimpin daerah di Indonesia sangatlah penting untuk menangani krisis. Salah satu pemimpin daerah yang menarik untuk dikaji gaya kepemimpinanya adalah Dedy Yon Supriyono selaku Walikota Tegal yang tengah menjabat pada periode 2019-2024. Dedy sempat menjadi perbincangan publik akibat beberapa kebijakan, ungkapan, dan pemasaran dalam bingkai komunikasi publiknya selama periode mengatasi pandemi COVID-19 di Kota Tegal. Citra positif Dedy selaku Walikota Tegal yang "dinilai" mampu menangani pandemi COVID-19 mencuat diranah publik. Maka dari itu ada korelasi antara gaya kepemimpinan populis Walikota Tegal, kebijakan populis yang dibuatnya, dan upaya membangun citra positif yang dilakukan ditengah pandemi COVID-19. Tulisan ini bertujuan untuk memberikan gambaran tentang bagaimana gaya kepemimpinan populis Dedy Yon Supriyono selaku Walikota Tegal dalam 
mengupayakan kebijakan populis untuk mengatasi pandemi COVID-19, serta tulisan ini akan mengidentifikasi mengenai upaya pembangunan citra positif melalui gaya kepemimpinan populis yang digunakan oleh Walikota Tegal selama periode pandemi COVID-19.

Ditambah lagi berdasarkan catatan dari Wall Street Journal Indonesia ${ }^{1}$ yang menilai bahwa kemunculan para pemimpin lokal populis sebagai generasi pembaharu politik, ini yang semakin membuat diskusi populisme di ranah pemimpin lokal lebih menarik untuk dikaji, apalagi jika melihat tempaan krisis akibat pandemi COVID-19 yang melanda seakan harus menguji kemampuan kepemimpinan para pemimpin lokal. Tulisan ini menggunakan metode kajian pustaka dengan memberikan fokus lebih terhadap diskusi populisme dan bagaimana Walikota Tegal yang dinilai sebagai pemimpin lokal populis sebagai aktor. Hal yang membuat penelitian ini semakin menarik adalah kajian gaya kepemimpinan populis yang ditempatkan pada keadaan krisis akibat pandemi COVID-19, yang mana keadaan ini merupakan keadaan yang belum terjadi pada masa sebelumnya. Keadaan ini juga turut mengguncang berbagai aspek kehidupan masyarakat, sehingga jika ditinjau dari kajian diskursus populisme sebelumnya yang kebanyakan membahas kajian gaya kepemimpinan populis pada kondisi normal, tulisan ini memiliki kelebihan pada sudut pandang kondisi masyarakat yang sedang tergoncang, tidak stabil, dan membutuhkan kepastian dari pemimpin lokalnya akibat pandemi COVID-19, sehingga ini juga memperbesar celah pemimpin lokal untuk melayangkan gaya kepemimpinan populis. Mendukung hal tersebut, Tegal adalah kota pertama di Indonesia yang melakukan lockdown, sehingga ini akan semakin melengkapi kajian populisme pemimpin lokal ditengah keadaan krisis akibat dari pandemi COVID-19.

\section{METODE PENELITIAN}

Tulisan ini menggunakan metode penelitian kualtitatif dengan teknik deskriptif analisis. Metode penelitian kualitatif adalah metode penelitian yang dilaksanakan pada setting tertentu yang terjadi dalam kehidupan nyata dengan fokus untuk menyelidiki dan memahami sebuah fenomena, seperti apa yang terjadi, mengapa itu terjadi, dan bagaimana itu terjadi (Chariri, 2009). Sedangkan teknik deskriptif analisis dapat diartikan sebagai prosedur pemecahan masalah yang diinvestigasi dengan menampilkan gambar subjek atau objek penelitian seperti individu, lembaga, kelompok dan masyarakat pada saat ini berdasarkan fakta tertulis, gambaran, dan sebagainya (Nawawi, 2015).

Tulisan ini menggunakan studi pustaka sebagai metode pengumpulan data untuk memberi gambaran mengenai gaya kepemimpinan populis dan kebijakan populis Walikota Tegal sebagai upaya untuk membangun citra positif dari pemimpin lokal ditengah pandemi COVID-19. Penulis mengumpulkan berbagai sudut pandang dan temuan literatur yang memiliki keterkaitan dengan fokus penelitian, seperti sumber-sumber dari buku, jurnal nasional/internasional, laporan, dokumen, teori, dan berita dari sumber yang kredibel (Nazir, 2004). Pada kerangka analisis, penulis pertama-tama membangun sebuah hipotesis awal mengenai fokus penelitian, khususnya pada teori kepemimpinan populis untuk membangun citra positif. Membangun sebuah hipotesis awal sangat penting guna menuntun analisis dari fenomena yang tengah diteliti. Selanjutnya ${ }^{1}$ Wall Street Journal Indonesia menyebutkan beberapa pemimpin lokal yang dianggap populis sebagai generasi
pembaharus politik tanah air. http://graphics.wsj.com/lists/INDOGEN_INA. Diakses pada 8 Agustus 2020 
maka peneliti akan melakukan analisis mendalam mengenai fokus penelitian untuk menguji hipotesis awal melalui data-data yang telah dikumpulkan dari upaya sudi pustaka. Sebagai fokus dari penelitian, maka artikel ini akan berfokus untuk memberikan gambaran mengenai gaya kepemimpinan populis dan kebijakan populis Walikota Tegal sebagai upaya membangun citra positif ditengah kondisi krisis akibat pandemi COVID-19.

\section{HASIL DAN PEMBAHASAN}

Populisme mengalami telah perkembangan yang signifikan dalam aras pemimpin lokal. Sebab dalam beberapa catatan dari para pengamat politik telah memberikan "gelar" sebagai sosok pemimpin lokal yang memulai strategi populisme ditanah air seperti bagi Jokowi saat memimpin Solo dan I Gede Winahasa di Jembrana dengan sejumlah kebijakan populisnya (Eko, 2007). Lalu disusul oleh pemimpin lokal lainya dengan gaya kepemimpinan populis untuk menghasilkan citra yang baik didepan publik seperti Tri Risma sebagai Walikota Surabaya, ada juga Walikota Bandung seperti Ridwan KamiL, Nurdin Abdullah selaku Bupati Bantaeng, dan Suryono selaku Bupat Bojonegoro. Mereka ini digambarkan sebagai sosok pemimpin yang langsung bersiggungan dengan masyarakat dan tidak ada kepentingan untuk memperkaya diri sendiri dengan jabatan atau bahkan turut menyuburkan para oligarki, kedibilitas mereka terbangun oleh upaya mereka sendiri sehingga citra publik memandang mereka baik (Savirani, 2016).

Sedangkan dalam periode saat ini yang sedang dipenuhi dengan kondisi ketidakpastian akibat pandemi COVID-19, para pemimpin diberbagai belahan dunia justru sedang diuji untuk menjaga konduktifitas masyarakat dan menangani virus, salah satu jalanya adalah dengan gaya kepemimpinan yang populis dan kebijakan yang populis. Kita disuguhkan oleh nama-nama seperti Donald Trump di Amerika, Jair Bolsonaro di Brazil, dan ada Jokowi di Indonesia yang merasa menjadi terdepan bersama rakyat yang mereka wakili ditengah pandemi COVID-19, seperti yang disampaikan oleh (Müller, 2016) bahwa pemimpin populis akan mengklaim bahwa dia adalah satu-satunya orang yang paling bisa mewakili kehendak masyarakat secara luas dengan menolak kehadiran pluralisme dalam masyarakat. Sedangkan dalam ranah pemimpin lokal ditanah air, periode krisis pandemi COVID-19 sempat melahirkan sosok pemimpin lokal yang "kelewat" populis dimulai dari kebijakannya hingga gaya kepemimpinanya yang "citra positifnya" dalam menanggulangi virus sudah dikenal publik. Namanya adalah Yon Supriyono selaku Walikota Tegal yang tengah menjabat dengan periode 2019-2024, Dedy sempat menjadi perbincangan publik akibat beberapa kebijakan, ungkapan, dan pemasaran dalam bingkai komunikasi publiknya selama periode mengatasi pandemi COVID-19 di Kota Tegal yang dianggap populis.

\section{Kebijakan dan Kepemimpinan Populis Walikota Tegal Pada Periode Pandemi COVID-19}

Pemimpin populis bisa diidentifikasi melalui berbagai kebijakan yang diimplementasikan untuk menangani permasalahan yang ada. Pada studi kasus Dedy selaku Walikota Tegal dalam menangani pandemi COVID-19, Dedy menerapkan beberapa kebijakan yang diidentifikasi sebagai kebijakan populis. Contohnya seperti melakukan Lockdown lokal dan merayakan optimisme 
biasnya dengan merencanakan melaksanakan pesta kembang api sebagai penutupan PSBB di Kota Tegal. Dimulai pada tanggal 23 Maret 2020, Walikota Tegal resmi mengumumkan untuk memberlakukan lockdown di Kota Tegal dengan tujuan mencegah terjadinya transmisi virus secara meluas. Kebijakan ini merupakan kebijakan lockdown pertama di Indonesia yang dilakukan oleh pemimpin lokal (Gunadha, 2020). Hal ini sontak membuat seluruh masyarakat Indonesia mengapresiasi keberanian dari Dedy selaku Walikota Tegal yang memberanikan daerahnya untuk melakukan lockdown namun tetap saja ada yang meragukan kebijakan tersebut, meski Jokowi selaku Presiden Republik Indonesia sempat "marah" akibat pemimpin lokal ini tidak melakukan koordinasi dengan pusat terlebih dahulu (Hidayat, 2020). Tindakan ini dinilai sangat populis karena selaras dengan (Savirani, Tornquist, \& Stoke, 2014) yang melihat populisme memiliki kecenderungan untuk melahirkan sentimentsentimen melawan kebijakan elit, dalam konteks pembahasan ini Dedy selaku Walikota Tegal sudah melawan kebijakan elit pusat yaitu pemerintah pusat (presiden) dengan tidak mengikuti kebijakan yang sudah ditetapkan mereka yaitu tidak melakukan lockdown lokal. Ditambah lagi dengan pernyataan Dedy didalam konferensi pers terkait satu warganya yang positif corona, di Balai Kota Tegal, yang dilansir oleh laman berita digital kompas.com (Setiadi, 2020), berikut pernyataanya:

"Warga harus bisa memahami kebijakan yang saya ambil. Kalau saya bisa memilih, lebih baik saya dibenci warga daripada maut menjemput mereka," Rabu (25/3/2020)

Pernyataan yang dilayangkan oleh Dedy terkesan sangat heroik, seperti apa yang digambarkan oleh (Lee, 2017) bahwa dalam momentum tertentu pemimpin populis bertindak bagaikan seorang pahlawan bagi masyarakatnya dan seakan "memaksakan" klaim bahwa kebijakanya adalah kehendak masyarakat (Müller, 2016). Selaras dengan itu fenomena ini juga turut mengamini (Paskarina et al., 2015) yang menyatakan bahwa para pemimpin populis tidak jarang memiliki kebijakan-kebijakan yang kontroversial dan berani berhadapan dengan elit.

Citra seorang Dedy selaku Walkota Tegal menjadi lebih baik, para pengguna media sosial twitter membicarakan perihal keberanian Dedy sebagai pemimpin lokal untuk melakukan lockdown lokal tersebut demi keselamatan masyarakat (Bruno, 2020). Langkah ini menjadi awal pembentukan citra positif Dedy sebagai pemimpin melalui gaya kepemimpinan populisnya dan kebijakan populis yang diambilnya, dengan ini popularitas Dedy semakin mencuat dijagat dunia maya dan menjadi perbincangan publik akibat dari keberhasilan Dedy atas gaya kepemimpinan populisnya untuk bisa membaca momentum. Pada kasus ini media massa juga berperan penting terhadap popularitas Dedy, sehingga apa yang dilakukan oleh Deddy menjadi berita dan perbicangan khalayak umum. Hal ini sebenarnya serupa dengan apa yang disampaikan oleh (Kendall \& C.Paine, 1995) seleksi penokohan kandidat dimulai dari bagaimana peran media massa untuk membentuk citra/gambaran dari tokoh tersebut, ada sebuah bagan yang dinamakan sebagai A Basic Model of Candidate Image Formation (CIF) untuk mempermudah proses pemahaman pendapat ini. 
Gambar 1.

A Basic Model of Candidate Image Formation (CIF)

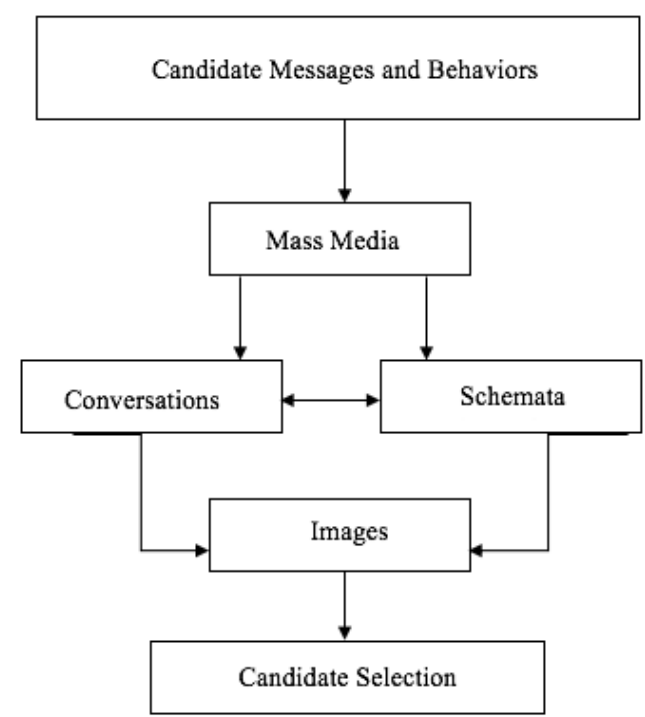

Masyarakat sebagai penerima pesan akan mengolah pesan dan tindakan yang dilakukan oleh aktor politik/kandidat yang disampaikan melalui media massa, setelah masyarakat sudah mendapatkan informasi dari media massa maka akan terjadi sebuah perbincangan didataran masyarakat mengenai apa yang telah aktor politik/kandidat itu katakan atau perbuat. Didalam perbicangan masyarakat ada juga dibarengi dengan proses Schemata, proses ini adalah sebuah bentuk justifikasi dan menguatkan kredibilitas pesan yang diperoleh dari aktor politik/kandidat. Sehingga tidak heran jika citra Dedy selaku Walikota Tegal dengan gaya kepemimpinanya yang populis ditengah pandemi COVID-19 sangat populer dengan keberanianya melakukan lockdown. Kebijakan lockdown lokal di Kota Tegal pun berakhir setelah Mentri Kesehatan memberikan izin kepada Pemkot Tegal untuk mengimplementasikan PSBB (Pembatasan Sosial Berskala Besar) pada 23 April 2020 (Putra, 2020), artinya bahwa Kota Tegal hanya mengalami lockdown selama kurang lebih satu bulan lamanya.

\section{Citra Positif Walikota Tegal}

Perbincangan mengenai bagaimana citra Walikota Tegal yang tampak bagaikan pahlawan di media massa terus digemakan, hingga citra Dedy selaku Walikota Tegal yang memberanikan diri untuk melakukan lockdown lokal demi keselamatan masyarakat dibahas hingga berbagai artikel manca negara dan disandingkan dengan berbagai pemimpin lokal dunia, seperti artikel yang berjudul These Local Leaders Are Standing Out in the Fight Against Coronavirus in Their Countries (VICE Asia Staff, 2020). Hal ini justru turut berkontribusi dalam meningkatkan citra positif Dedy sebagai pemimpin lokal yang populis untuk mengedepankan keselamatan rakyat dengan kebijakan populis yang kontroversial itu.

Upaya Dedy yang populis untuk terus membangun citra positif ditengah pandemi COVID-19 tidak hanya diimplementasikan melalui kebijakanya, namun juga diimplementasikan oleh Dedy melalui mekanisme pemasaran citra. Dalam 
upaya Dedy untuk menggemakan bahwa dirinya yang terkesan pro rakyat karena telah berani melakukan lockdown lokal pertama di Indonesia, maka Dedy telah merancang gambar dirinya dengan pakaian yang khas dan menyebut dirinya sebagai Mr.Lockdown (PanturaPost, 2020), ditambah lagi dengan lagu Tegalan yang menceritakan tentang kebanggaan masyarakat Kota Tegal karena memiliki Dedy sebagai Mr.Lockdown.

Gambar 2. Iklan Dedy Selaku Walikota Tegal yang Disebut Sebagai Mr.Lockdown Sumber: Hasil Pencarian Google

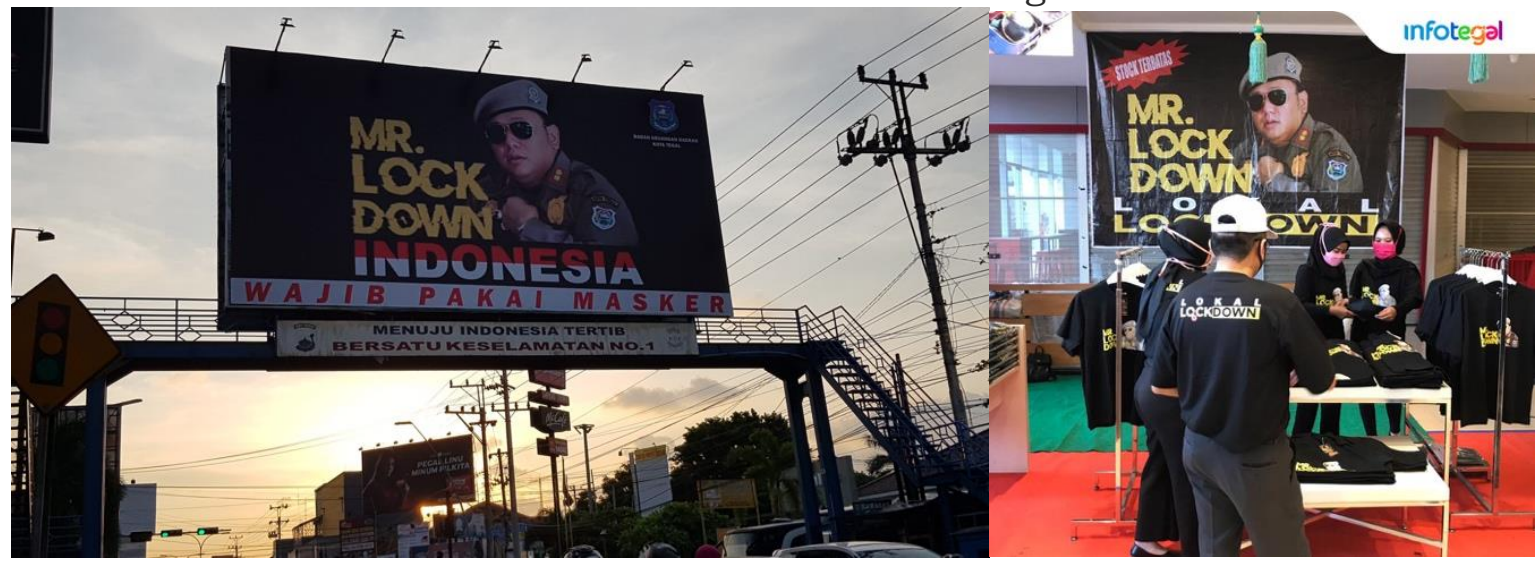

Gambar 3. Lagu Tegalan Mr.Lockdown Sumber: Laman Facebook smpantura.com

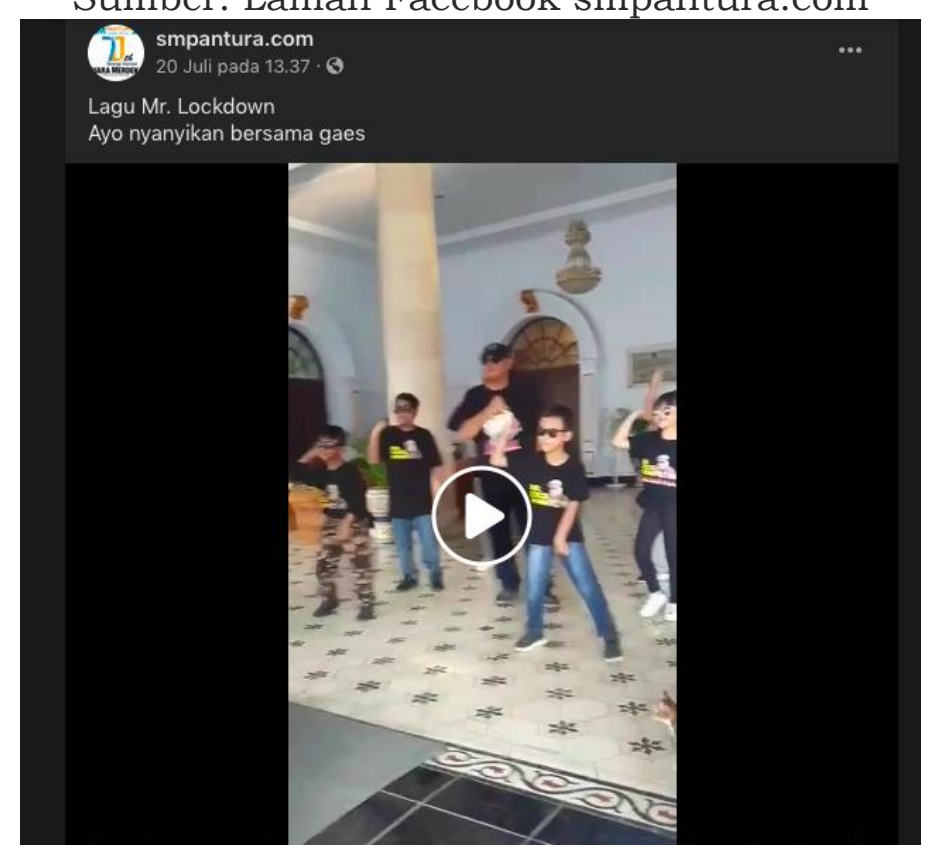

Dedy menggambarkan citranya sebagai sosok pahlawan yang telah berani melakukan lockdown lokal pertama di Indonesia dengan membuat billboard dan kaos yang bergambarkan dirinya, ditambah lagi Dedy menyebut dirinya sebagai Mr.Lockdown untuk memperkuat citranya bahwa dia telah melakukan lockdown lokal pertama di Indonesia demi keselamatan masyarakat Kota Tegal. Upaya pembentukan citra yang sama juga tetap dilakukan oleh Dedy dengan membuat 
lagu Tegalan tentang Mr.Lockdown, lagu ini menggambarkan kebanggaan masyarakat Kota Tegal karena telah memiliki Dedy sebagai Mr.Lockdown yang telah menyelamatkan masyarakat dari bahaya pandemi COVID-19 dengan kebijakan lockdown.

Citra Dedy melalui media Billboard, kaos, dan lagu Mr.Lockdown juga sempat menjadi perbincangan publik, seperti halnya teori A Basic Model of Candidate Image Formation (CIF) dari (Kendall \& C.Paine, 1995) yang menggambarkan citra aktor politik dihasilkan dari media massa yang menjadi obrolan publik, lalu publik memutuskan apakah citra tersebut baik ataupun buruk. Sebab gambar mengenai billboard, kaos dan lagu Mr.Lockdown ini sudah tersebar diberbagai media dan menjadi perbincangan khalayak umum.

Upaya Dedy melakukan hal ini bisa dikategorikan sebagai sebuah pencitraan, sebab menurut (Ries \& Trout, 2001) ada dua elemen penting dalam upaya pencitraan. Pertama adalah positioning, mengena bagaimana cara memberi ruang untuk sebuah produk didalam pikiran konsumen. Dedy melalui media billboard, kaos, dan lagu ini sudah memposisikan dirinya sebagai penolong untuk masyarakat (konsumen) ditengah krisis akibat pandemi COVID19, sehingga dia terkenal sebagai pemimpin daerah yang berbeda dari pemimpin daerah lainya (diferensiasi). Di setiap wawancaranya di media juga Dedy menggambarkan dirinya sangat mementingkan keselamatan masyarakat dengan menetapkan kebijakan lockdown lokalnya, meski tidak semua masyarakat Kota Tegal setuju akan kebijakan tersebut, namun Dedy tetap selalu memasarkan sebutan Mr.Lockdown. Kedua adalah memory, manusia pada dasarnya adalah selektif dalam menerima informasi untuk disimpan didalam pikiranya, karena pikiran manusia cenderung selektif dalam meneirma informasi maka hanya informasi yang dinilai penting saja yang bisa masuk kedalam pikiran manusia untuk disimpan. Pikiran manusia juga lebih suka untuk menerima sebuah informasi yang tidak rumit atau sederhana. Kebijakan Dedy untuk memberlakukan lockdown lokal pertama di Indonesia merupakan sebuah kebijakan kontroversial yang menurut (Paskarina et al., 2015) sebagai salah satu karakteristik pemimpin populis, ditambah lagi dengan hadirnya billboard, kaos, dan lagu terkait dengan sebutan Mr.Lockdown. Maka nama Dedy sebagai Mr.Lockdown yang telah melaksanakan lockdown lokal pertama di Indonesia bagaikan seorang pahlawan sudah tertancap dipikiran masyarakat, jika mendengar kata Mr.Lockdown maka publik akan tertuju pada Dedy selaku Walikota Tegal.

\section{Optimisme Bias Kepemimpin Populis Dedy Ditengah Pandemi COVID-19}

Dalam beberapa waktu terakhir, perdebatan mengenai kemampuan dari pemimpin populis ditengah pandemi COVID-19 sempat mencuat dan menjadi perdebatan publik. Seperti apa yang disebutkan oleh artikel dengan judul Are populist leaders a liability during COVID-19? oleh (Lassa \& Booth, 2020), menyebutkan contoh pemimpin populis ditengah pandemi seperti Donald Trump di Amerika, Jair Bolsonaro di Brazil, dan ada Jokowi di Indonesia. Lassa dan Booth memaparkan sikap optimistic bias sebagai kecenderungan karakter dari pemimpin populis ditengah pandemi COVID-19. Sikap tersebut sangat nampak melekat pada Dedy selaku Walikota Tegal di periode pandemi COVID-19.

Pertama optimistic bias, jenis pemimpin ini memiliki sikap yang optimisme yang berlebihan namun bias. Mereka percaya bahwa mereka memiliki 
kemampuan yang layak atau bahkan lebih baik dalam merespon krisis akibat pandemi COVID-19, jenis pemimpin seperti ini pada umumnya sangat rentan terhadap rasa puas diri dengan menganggap bahwa mereka memiliki kemungkinan yang relatif lebih kecil untuk terdampak sebuah masalah dibandingkan dengan pemimpin-pemimpin lainya. Dedy nampak memiliki optimisme yang berlebihan namun bias dalam menangani krisis akibat pandemi COVID-19, hal ini dibuktikan dengan rencana pengadaan pesta kembang api sebagai penutupan kebijakan PSBB di Kota Tegal (Anwar, 2020), meskipun agenda tersebut sudah dibatalkan namun Dedy berhasil menunjukan sebuah optimisme yang berlebihan dan menganggap dirinya berhasil merespon krisis akibat pandemi COVID-19.

\section{Gambar 4. Pesta Kembang Api Paska Penutupan Kebijakan PSBB di Kota Tegal} Sumber: metrotvnews.com

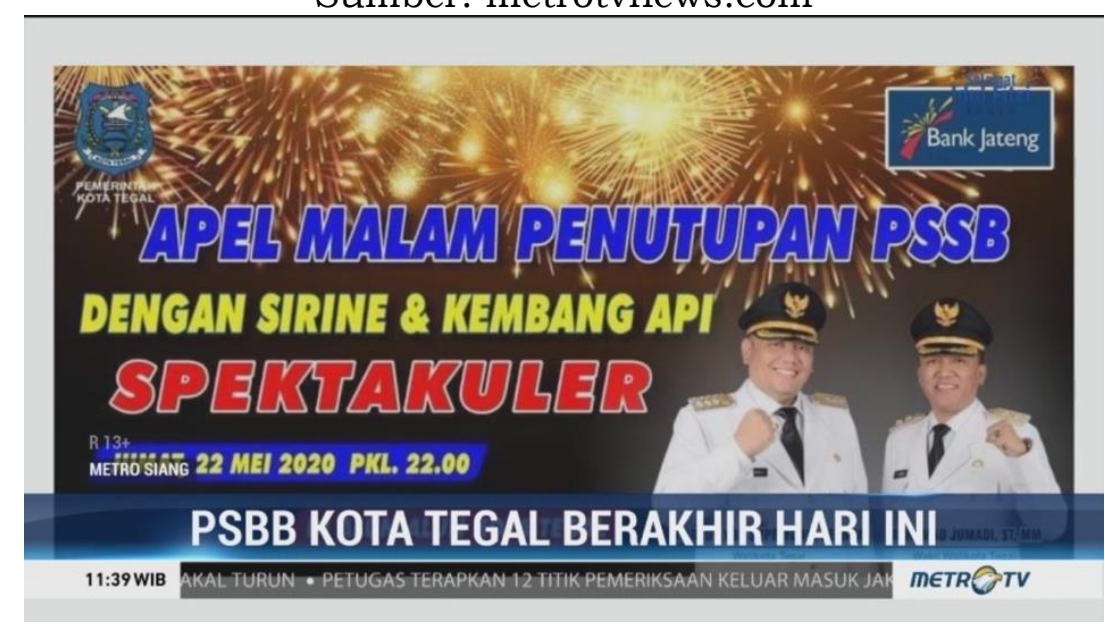

Dengan adanya agenda ini, Dedy berpikir bahwa semuanya akan baik-baik saja dan bisa merayakanya dengan pesta kembang api di Kota Tegal yang meriah. Dedy secara gamblang menganggap remeh keadaan krisis akibat pandemi COVID-19 dan tidak menghiraukan ancaman serangan gelombang kedua pandemic COVID-19 di Kota Tegal. Hal ini justru berbahaya bagi masyarakat Kota Tegal, faktanya serangan pandemi COVID-19 kembali datang menyerang Kota Tegal dengan ditemukanya 26 kasus positif COVID-19 dan disinyalir akan terus bertambah meski sebelumnya sudah dianggap menjadi zona hijau (Farasonalia, 2020). Sikap optimistic bias sangat berbahaya untuk dimiliki seorang pemimpin dalam merespon krisis akibat pandemi COVID-19, pasalnya rasa cepat puas diri menurunkan kewaspadaan.

\section{PENUTUP}

Kemunculan pemimpin lokal yang populis dalam merespon krisis akibat pandemi COVID-19 memang sedang benar-benar meningkat tajam, minimal kemunculan mereka dapat memberikan rasa aman kepada masyarakat dalam jangka waktu yang pendek. Dedy selaku walikota Tegal yang menjabat pada periode 2019-2024, dalam momentum periode krisis akibat pandemi COVID-19 Dedy telah mengimplementasikan gaya kepemimpinan dan kebijakan populisnya. Kebijakan populisnya dapat dilihat melalui pemberlakuan lockdown lokal yang kontroversial dan dianggap melawan pemerintah pusat, ditambah lagi 
perihal mengenai wacana untuk melaksanakan pesta kembang api untuk merayakan selesainya PSBB di Kota Tegal sebagai bentuk optimisme bias.

Sedangkan dalam gaya kepemimpinan populis Dedy selama periode pandemi COVID-19 sangat terlihat dari bagaimana dia melontarkan diksi-diksi kata yang terkesan pro-rakyat, bertindak layaknya pahlawan, dan menganggap bahwa kebijakanya bisa mewakili seluruh masyarakat yang ada. Gaya kepemimpinan populisnya semakin terlihat manakala sebutan Mr.Lockdown disematkan kepada dirinya, sehingga Dedy terlihat sebagai sosok pahlawan ditengah pandemi COVID-19 bagi masyarakarnya. Hal-hal tersebut juga berkontribusi atas terbentuknya citra positif dari Dedy selaku walikota Tegal dalam merespon dan menangani keberadaan pandemi COVID-19. Dedy menjadi perbincangan publik hingga dikancah internasional, sehingga peran media juga tak luput dalam mempublikasikan berbagai kebijakan dan gaya kepemimpinan populis Dedy sebagai upaya meningkatkan citra positifnya.

\section{DAFTAR PUSTAKA}

Anwar, F. (2020). Viral Tegal Pesta Kembang Api, Berakhirnya PSBB Bukan Berarti Aman Corona. Detikhealth.Com. https://health.detik.com/beritadetikhealth/d-5024391/viral-tegal-pesta-kembang-api-berakhirnya-psbbbukan-berarti-aman-corona

Bruno, L. (2020). Wali Kota Tetapkan Lockdown, Netizen Riuh Cuitkan Soal Tegal. Cnnindonesia.Com.

Canovan, M. (1999). Trust the people! populism and the two faces of democracy. Political Studies. https:/ / doi.org/10.1111/1467-9248.00184

Chariri, A. (2009). Landasan filsafat dan metode penelitian kualitatif. In Workshop Metodologi Penelitian Kuantitatif dan Kualitatif, Laboratorium Pengembangan Akuntansi (LPA), Fakultas Ekonomi Universitas Diponegoro Semarang, 31 Juli - 1 Agustus 2009.

Collins, R. M. (1989). The originality trap: Richard hofstadter on populism. Journal of American History. https: / / doi.org/10.2307/1908347

Eko, S. (2007). Dari Daerah Budiman, Menuju daerah Sejahtera. Jurnal MANDATORY, 3(3).

Farasonalia, R. (2020). Ada 26 Kasus Covid-19 di Tegal, Ini Perintah Ganjar kepada Wali Kota Dedy. Kompas.Com.

Fitra, S. (2020). Pandemi Covid-19 yang Terlambat Diantisipasi Indonesia. Katadata.Co.Id. https://katadata.co.id/analisisdata/2020/03/26/pandemicovid-19-yang-terlambat-diantisipasi-indonesia

Gidron, N., \& Bonikowski, B. (2013). Varietis of Populism: Literature review and Research Agenda (No. 13-0004). https://scholar.harvard.edu/files /gidron_bonikowski_populismlitreview_201 3.pdf

Goodhart, C., \& Lastra, R. (2018). Populism and Central Bank Independence. Open Economies Review. https://doi.org/10.1007/s11079-017-9447-y

Gunadha, R. (2020). Pertama di Indonesia, Wali Kota Umumkan Tegal Lockdown! Suarajawatengah.Id.

Hadiz, V. R., \& Robison, R. (2017). Competing populisms in post-authoritarian Indonesia. International Political Science Review. https: / / doi.org/10.1177/0192512117697475

Hidayat, F. (2020). Terapkan Lockdown, Jokowi Marah ke Wali Kota Tegal dan 
Tasik? Wartaekonomi.Co.Id.

Ihsanuddin. (2020). Fakta Lengkap Kasus Pertama Virus Corona di Indonesia. Kompas.Com.

Kendall, K. E., \& C.Paine, S. (1995). Political Image and Voting Decisions. In K. L.Hacker (Ed.), Candidate image In Presidential Election. Praeger.

Kusumo, R., \& Hurriyah, H. (2019). Populisme Islam di Indonesia: Studi Kasus Aksi Bela Islam oleh GNPF-MUI Tahun 2016-2017. Jurnal Politik. https://doi.org/10.7454/jp.v4i1.172

Laclau, E. (2005). On Populist Reason (Phronesis). Verso.

Lassa, J. A., \& Booth, M. (2020, April 8). Are populist leaders a liability during COVID-19? The Conversation.

Lee, A. (2017, November 10). Kepahlawanan dalam Intipan Populisme. Kompas.Com. https://kompas.id/baca/x/politik/2017/11/10/kepahlawanan-dalamintipan-populisme/

Mawardi, I. (2020, April 6). Ini Daftar 37 Pernyataan Blunder Pemerintah Soal Corona Versi LP3ES. Detiiknews.Com.

Mietzner, M. (2015). Reinventing Asian Populism: Jokowi's Rise, Democracy, and Political Contestation in Indonesia. Policy Studies.

Müller, J.-W. (2016). What Is Populism? University of Pennsylvania Press.

Nawawi, H. (2015). Metode Penelitian Bidang Sosial. UGM Press.

Nazir. (2004). Metode Penelitian. Metode Penelitian.

Nimmo, D. (1976). Political Image Makers and the Mass Media. The Annals of the American Academy of Political and Social Science. https: / / doi.org/10.1177/000271627642700105

Nuraini, R. (2020). Kasus Covid-19 Pertama, Masyarakat Jangan Panik.

PanturaPost. (2020). Billboard "Mr. Lockdown Indonesia" Bergambar Wali Kota Tegal Tuai Pro Kontra. Kumparan.Com. https: / /kumparan.com/panturapost/billboard-mr-lockdown-indonesiabergambar-wali-kota-tegal-tuai-pro-kontra-1tRJTZwYGuA

Paskarina, C., Asiah, M., \& Madung, O. G. (2015). Berebut kontrol atas kesejahteraan: Kasus-kasus politisisasi demokrasi di tingkat lokal. Research Center for Politics and Government (PolGov).

Pratikno, \& Lay, C. (2013). From Populism to Democratic Polity: Problems and Challenges in Solo, Indonesia. In Democratization in the Global South. https: / /doi.org/10.1057/9780230370043_12

Putra, P. M. S. (2020, April 17). Menkes Terawan Resmi Izinkan PSBB Tegal. Liputan6.Com.

Ries, A., \& Trout, J. (2001). Positioning: The Battle for Your Mind: In McGraw-Hill Professional. https://doi.org/10.13140/RG.2.1.1523.3120

Rosenberg, S. W., Kahn, S., \& Tran, T. (1991). Creating a political image: Shaping appearance and manipulating the vote. Political Behavior. https: / / doi.org/10.1007/BF00992868

Sahab, A. (2017). Realitas Citra Politik Tri Rismaharini. Masyarakat, Kebudayaan Dan Politik. https://doi.org/http://dx.doi.org/10.20473/mkp.V30I12017.20-33

Savirani, A. (2016). Negara, Bisnis yang Terkonsolidasi, dan Pemimpin Populis Baru. Research Centre for Politics and Government, Department of Politics and Government, Fisipol UGM dan PCD Press. 
Savirani, A., Tornquist, O., \& Stoke, K. (2014). Demokrasi di Indonesia: Antara Patronase dan Populisme. Ringkasan Eksekutif Project Power, Welfare, and Democracy, Universitas Gadjah Mada \& Oslo University.

Setiadi, T. (2020). Tegal Terapkan "Local Lockdown", Wali Kota: Lebih Baik Saya Dibenci Warga Daripada... Kompas.Com.

VICE Asia Staff. (2020, April 22). These Local Leaders Are Standing Out in the Fight Against Coronavirus in Their Countries. Vice.Com. 